\title{
Britain moves to curtail new drug craze
}

Published at www.cmaj.ca on Apr. 26

A lmost unheard of a year ago, mephedrone exploded onto the recreational drug scene in the United Kingdom last summer as users began looking for alternatives after the supply of the drug "ecstasy" dried up across Europe.

It quickly became the drug of choice for many. It was cheap and legal. It could be purchased on the Internet, where it was benignly marketed as plant food. Companies even delivered it to the door.

Yet almost as quickly, 4methylmethcathinone - one of a family of drugs that derives from the flowering khat shrub, which is chewed as a stimulant in Africa, similar to coca leaves from South America - came under intense media scrutiny.

Its use was tagged as "epidemic" when two young men - Nicholas Smith, 19, and Louis Wainwright, 18 - were found dead after taking it on a night out. Demands escalated to have it declared illegal. Headlines declared that as many as 20 people had died under mephedrone's influence. One headline screamed: "Boy rips off own scrotum after taking mephedrone." Another asserted: "Man blasts himself in face with shotgun after mephedrone party."

The British government moved to act, deeming the drug illegal on Apr. 16 as a Class B substance under the Misuse of Drugs Act, which carries a maximum sentence of five years in prison for possession and up to 14 years if caught trafficking.

"We are determined to act to prevent this evil from hurting the young people of our country," British Prime Minister Gordon Brown told the House of Commons on Mar. 24.

By contrast, there is no evidence that mephedrone has become a problem in Canada, although experts say that may be because cathinone and an analogue, methcathinone, are grouped with

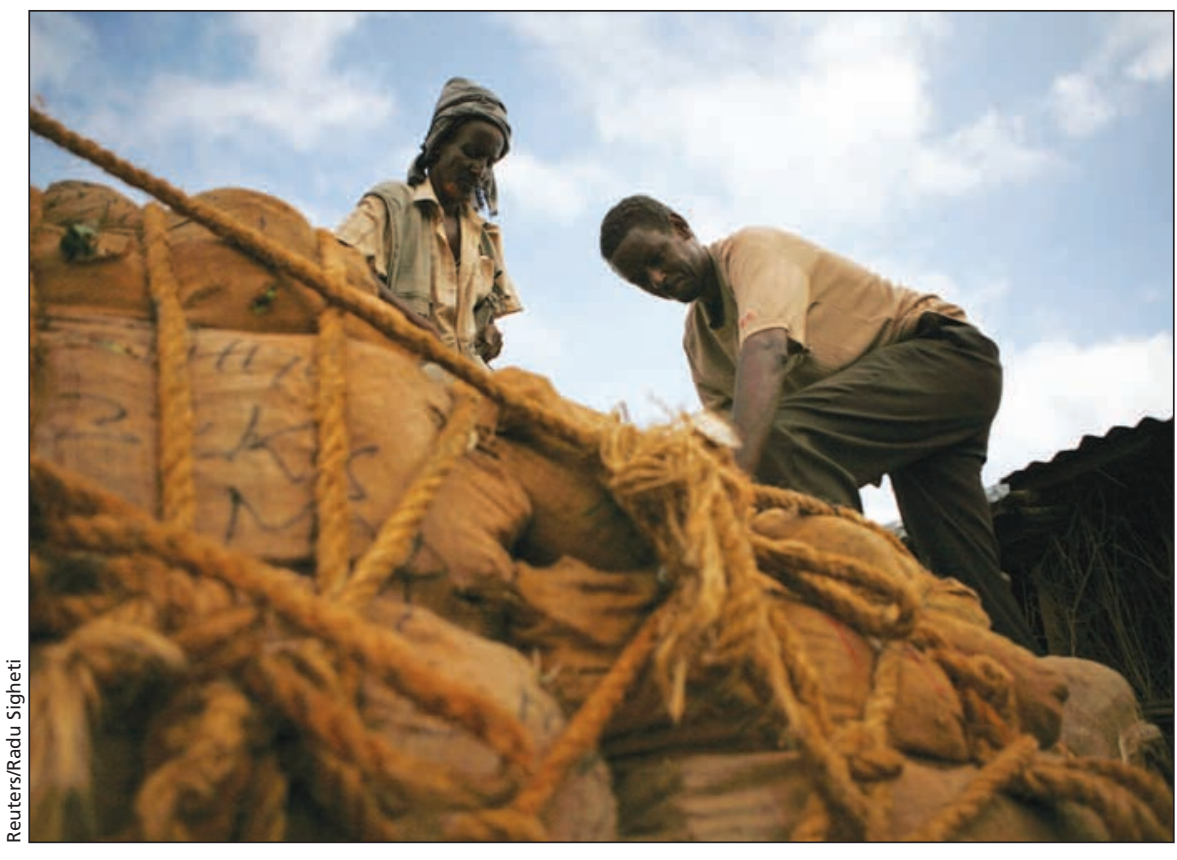

Mephedrone is derived from an African shrub called khat, which is grown in the foothills of Mount Kenya and chewed as a mild stimulant. Khat's active ingredient is cathinone, an amphetamine-like substance that can produce a euphoric state for up to 24 hours.

other amphetamines as Schedule III controlled substances.

Typically snorted or swallowed, mephedrone's effects last a few hours, but can last days if taken during binges. Those effects include a head rush followed by a sense of euphoria, boundless energy and talkativeness. But other effects include a bloody nose, dilated pupils and erratic heartbeat. Comedowns are usually characterized by fatigue, dizziness and mild depression.

"We were absolutely flabbergasted just at how popular mephedrone grew," says Duncan Dick, an editor for MixMag, a popular club magazine. In their 2009 drug survey, more than $40 \%$ of respondents indicated that they had tried mephedrone, also known as "m-cat" or "meow meow," at least once, making it the fourth most popular drug in the UK after marijuana, cocaine and ecstasy.

"I'm not flabbergasted at all. It makes perfect sense that people would be using it," says Dr. Luke Mitcheson, a clinical psychologist and a lead researcher on the survey. Those surveyed are often pioneers of drug-taking and it is reasonable to assume they would be drawn to this type of stimulant. "You don't have to go through a drug dealer, you can get it online and lots of people are saying good things about it," he says.

A 24-year-old woman says privately that she began using mephedrone because "everyone else was raving about how fun it was and that it was really cheap. It was really fun. I was quite hyper and really on it. I wanted to dance and got all lovey with friends."

Dick says no particular social scene is related to mephedrone use, unlike ecstasy's association with the techno music scene. But it does appear that previous users of other drugs are more inclined to try mephedrone.

A 24-year-old man says he wasn't won over until he tried mephedrone a second time, when a group of 10 mix- 
and-match friends, some with dreads, others with orange mohawks, sat around drinking cider and beer while cutting up lines of mephedrone and discussing philosophy, workers' rights and tragic tales of consumerism.

"I finally got why people were doing it," he says. "I felt very alert, very happy, very chatty and very sociable. ... When I got more and more into it, it became an antisocial thing. I wouldn't want to be with anyone or talk to anyone."

The explosive growth in mephedrone's use was also a function of its low cost and ready availability, experts say.

"Global web-based distribution and global communications markets allow new drugs to be rapidly shared," says Dr. Adam Winstock, a psychiatrist at the UK's National Drug and Alcohol Research Centre and the other lead researcher on the MixMag survey.
One vendor, NaughtyPlantFood.com, began selling mephedrone in November. A spokesperson, who refused to be named, said "phenomenal" demand and a close link to a supplier in China persuaded the firm to easily get in on the act. "We haven't seen sales like this with any other type of business," he wrote in an email.

The firm sells a gram of mephedrone for about $20 \%$ of the cost of a gram of cocaine on the street.

Canadian authorities appeared mystified when asked about the drug.

"Methcathinone? I'm going to have to Google it," said RCMP communications strategist Robin Percival. She later wrote in an email that "it is not an issue in Canada at this point, and to our knowledge, it has never been seized here."

Ottawa, Ontario-based lawyer Eugene Oscepella says the limited extent to which mephedrone has thus far invaded Canada may be a function of umbrella drug policies that limit the ability to sneak drugs into Canada. "There's a provision in the substance act that says analogues of certain drugs and other similar drugs may be illegal too," he says. "It's a catch-all provision."

Yet, experts say that doesn't mean mephedrone won't eventually arrive on Canadian shores. "We haven't solved the issues of drugs even where there is clear illegality," says Dan Reist, assistant director at the Centre for Addictions Research of British Columbia. "There's no legal loopholes around cocaine and yet it's a major drug. The idea that legal prohibition will somehow be the answer to closing down drug markets is ill-informed." - Allison Elwell, Ottawa, Ont.

DOI:10.1503/cmaj.109-3245 